IZA DP No. 117

IAB Employment Subsample 1975-1995 Opportunities for Analysis Provided by the Anonymised Subsample

Stefan Bender

Anette Haas

Christoph Klose

February 2000 


\title{
IAB Employment Subsample 1975-1995 \\ Opportunities for Analysis Provided by the Anonymised Subsample
}

\author{
Stefan Bender \\ Institute for Employment Research (IAB) and IZA, Bonn \\ Anette Haas \\ Institute for Employment Research (IAB) \\ Christoph Klose \\ Bundesanstalt für Arbeit, BA \\ Discussion Paper No. 117
February 2000 \\ IZA \\ P.O. Box 7240 \\ D-53072 Bonn \\ Germany \\ Tel.: +49-228-3894-0 \\ Fax: +49-228-3894-210 \\ Email: iza@iza.org
}

This Discussion Paper is issued within the framework of IZA's research areas Mobility and Flexibility of Labor Markets, The Welfare State and Labor Markets and The Future of Work. Any opinions expressed here are those of the author(s) and not those of the institute. Research disseminated by IZA may include views on policy, but the institute itself takes no institutional policy positions.

The Institute for the Study of Labor (IZA) in Bonn is a local and virtual international research center and a place of communication between science, politics and business. IZA is an independent, nonprofit limited liability company (Gesellschaft mit beschränkter Haftung) supported by the Deutsche Post AG. The center is associated with the University of Bonn and offers a stimulating research environment through its research networks, research support, and visitors and doctoral programs. IZA engages in (i) original and internationally competitive research in all fields of labor economics, (ii) development of policy concepts, and (iii) dissemination of research results and concepts to the interested public. The current research program deals with (1) mobility and flexibility of labor markets, (2) internationalization of labor markets and European integration, (3) the welfare state and labor markets, (4) labor markets in transition, (5) the future of work, (6) project evaluation and (7) general labor economics.

IZA Discussion Papers often represent preliminary work and are circulated to encourage discussion. Citation of such a paper should account for its provisional character. 
IZA Discussion Paper No. 117

February 2000

\title{
ABSTRACT \\ IAB Employment Subsample 1975-1995 \\ Opportunities for Analysis Provided by the Anonymised Subsample
}

The IAB employment subsample is now available for researchers in a third, anonymised version. Following the so-called basic file and the regional file from the IAB employment subsample, which encompassed the years 1975 to 1990, the actualized version of the basic file covers now the years 1975 to 1995 and contains for the first time information on Eastern Germany for the period 1992 to 1995.

Therefore, the IAB employment subsample is equipped with data of one percent of all employees registered by the social insurance system within the given period of 21 years. This data has been stored into a file by the Federal Employment Service (Bundesanstalt für Arbeit) to provide an insurance account for each employee recorded by the German social insurance system. Supplementary information on establishments and on unemployment periods in which a claimant received benefits was added to the sample.

This version now contains exact daily flow information on the employment history of 559,540 persons as recorded by the social insurance system and on periods of drawing benefits as well. It allows to reproduce employment careers without typical problems of longitudinal surveys which do arise in social research (e.g. panel mortality, memory gaps). Nevertheless there are specific problems that appear as a result of the data generation process.

In general, data from the employment statistics like the IAB employment subsample is subject to confidentiality under Social Code Book X. Passing this data to third parties would have made complicated approval procedures necessary. To avoid such difficulties the IAB decided on the anonymisation of the data with a procedure based on the factual anonymisation under the Federal Statistics Act. The project could only be realized with financial assistance from the scientific community. Along with the anonymising of personand establishment-related cross-section information, the longitudinal information of the persons involved had to be anonymised factually, too. The procedure mainly consisted in the aggregation of the characteristics and in a shift of the complete employment history of each person on the time axis. Comparing the anonymised with the original IAB employment subsample it is shown that the anonymising procedures do not place any serious constraints on the analysis potential of the file. Though the distribution of establishment transitions along the time axis cannot not be reproduced with the anonymised IAB employment subsample, cross-section comparisons of stocks at an historical point in time and multivariate models aiming at daily accuracy (e.g. piecewise constant exponential models) do not lead to any deviations of the results between the two files. The anonymised IAB employment subsample, which is available to researchers through the Central Archive for Empirical Social Research at the University of Cologne, is, therefore, one of the most important German sources for employment market research.

JEL Classification: C1, C2, C3, C41, J1, J2, J3, J4, J5, J6, J7

Keywords: Data set description, statistics, econometric modelling, labor market, unemployment, employment, wage, mobility, flexibility, working life

\author{
Stefan Bender \\ Institute for Employment Research \\ Regensburger Str. 104 \\ 90327 Nuremberg \\ Germany \\ Email: stefan.bender@iab.de
}




\section{Introduction - Data Access}

Employment statistics are one of the most important official data sources for labour economics (Alba et al. 1994). In order to make microdata from this data source available to researchers, the Institute for Employment Research (IAB), the Centre for Survey Research and Methodology in Mannheim (ZUMA), the Social Science Research Center Berlin (WZB) and the GESIS ${ }^{1}$, carried out an initial joint project to anonymise this data factually (cf. Bender et al. 1996). For reasons of data protection, detailed establishment and regional data cannot be passed on in a file at the same time, so that two separate data files were anonymised. A regional file, which allows analyses on the basis of the district numbers (cf. Haas / Hilzendegen 1997) was added as a second independent file to the basic file, which contains a system-free establishment number. These two files cover the period 1975 to 1990.

Since February 1996 (basic file, ZA number: 2640), and March 1997 (regional file, ZA number: 2842), these files have been available to researchers through the Central Archive for Empirical Social Research at the University of Cologne (abbreviated throughout as "ZA"). Users must pay the standard ZA fees when ordering a data file (cf. ZA-Information 1996). Since then, the ZA has supplied the basic file to 40 institutions, and the regional file to 6 institutions. A series of papers based on the IAB employment subsample have also been published. Some examples, and this is not a full list, are in the appendix. Since August 1999, a "new version" of the basic file is available under the ZA number 3136. The anonymisation of this file was realized in the context of the research project "Splitting or exclusion? Employment market segmentations and fluctuations in Eastern and Western Germany", conducted by Professor Dr. Peter A. Berger, Chair of MacroSociology (University of Rostock) and co-financed by the German Research Association $(\mathrm{DFG})^{2}$. At present, anonymisation of a new regional file is being carried out (project title "Regional adjustment processes in the Federal Republic of Germany with particular consideration of the territorial mobility of employees", by Professor Dr Joachim Möller, Chair of Economics, Empirical Macroeconomics and Regional Economy, University of Regensburg). The anonymised file will probably be available through the ZA at the end of 2001 .

The ZA can pass the database to external researchers if they submit an application for the use of the database for a specific project with a time limit. In practice, the researcher has to submit a project application to the ZA with a project description of at least two pages in which the project title, duration and staff members are given. On the basis of this project description the IAB decides on permission of data usage. In case of a positive decision by the IAB the ZA makes an agreement with the recipient of the data (cf. Fig. 1). There is a simplified procedure for users who started their project with the IAB employment subsample 1975-1990 (basic file) and wish to continue their analyses with the new sample.

Unfortunately, the IAB employment subsample can only be distributed to users in Germany. Researchers working outside the country can only gain access to the data

\footnotetext{
${ }^{1}$ GESIS is an infrastructural association which supplies fundamental social science services on a national and international level, both in terms of theory and practice. GESIS consists of the institutes $\underline{\mathrm{ZZ}}, \underline{\mathrm{ZA}}, \underline{\mathrm{ZUMA}}$, and keeps a branch office in Berlin.

${ }^{2}$ DFG is the central public funding organization for academic research in Germany. DFG is thus comparable to a Research Council (in British and Western European terminology) or a (national) Research Foundation (in American and Far Eastern terminology).
} 
through research periods spent in Germany, or must/may carry out their analyses in cooperation with a researcher living in Germany. An improvement of this situation may turn up as a result of the harmonisation and standardisation of national data protection laws at EU level.

*** Figure 1: Data access

The IAB employment subsample 1975-1995 is divided into two files, which can be linked by means of a system-free personal number and a spell counter. The spell counter indicates the reference number of the row for a person.

One of the two files can be compared to the comprehensive file, which is already known from the earlier versions of the IAB employment subsample (IABS7595.DAT). This file contains all data on employees covered by the social insurance system, benefits recipients and selected establishment information (industry, establishment size). ${ }^{3}$ For this purpose, the establishment information was added to each record with the help of the establishment number, and the employment year. The data for benefits recipients was arranged in the employment notifications in the correct time sequence. This file has about $471 \mathrm{MB}$, so that it was compressed to $99 \mathrm{MB}$ using a zip program (ZOO).

The second file contains additional establishment information that is not relevant to all users. Aggregations are carried out in this file using the establishment number from the IAB's establishment file of the employment statistic, which is available from 1977 to the current margin. The additional characteristics are the proportions of unskilled/semi-skilled persons, of persons with vocational training and of persons with higher/university education. Start and end years for the establishments are also included. This annual information designates the first and the last year for which there is an entry of this establishment number in the IAB's establishment file. The information, therefore, can be interpreted as years in which an establishment was founded or closed down. This file has $188 \mathrm{MB}$ (original) or $33 \mathrm{MB}$ (compressed).

The compressed file, which has 659,221,308 Bytes $^{4}$ decompressed, and 131,831,566 Bytes in a compressed format, does not have to be decompressed if the user decides to use the statistic software TDA $^{5}$ (c.f. Rohwer 1994, Rohwer 1996, Rohwer / Pötter 1999). TDA is available in the Internet via ftp://stat.ruhr-uni-bochum.de/pub/tda (WWW address: http://www.stat.ruhr-uni-bochum.de).

The IAB employment subsample 1975 - 1995 contains exactly a total of 7,847,553 notifications; 6,711,153 notifications are from Western Germany, and 354,091 from Eastern Germany, accumulated by 559,540 persons. On the basis of the final notification in each case, the file contains 483,327 Western Germans and 76,213 Eastern Germans.

A description of the data is given below in Chapter 2; the anonymisation procedure and the changes of characteristics are outlined briefly in Chapter 3. The restrictions for users

\footnotetext{
The following chapter contains a description of the data file.

4 The ZOO archive contains also a variables description file which was included in the information on establishment size.

$5 \quad$ TDA = Transition Data Analysis: "The term transition data, adapted from Lancaster (1990), is used in a broad sense to denote all kinds of data containing information about changing states of individuals or other units of analysis" (Rohwer 1994, 1-1.2).
} 
caused by the anonymisation are examined by comparisons of the anonymised and the original IAB employment subsample 1975-1990, in detail by means of cross-section comparisons of stocks, the distribution of establishment transitions over a period in Chapter 4 and the assessments results of a piecewise constant exponential model in Chapter 5. The paper concludes with some final remarks.

\section{The IAB employment subsample - data characteristics}

The basis of the IAB employment subsample ${ }^{6}$ is the integrated notifying procedure for health insurance, statutory pension scheme and unemployment insurance (DEVO/DÜVO) ${ }^{7}$ which was introduced with effect from 1 January 1973 (c.f. Fig. 2). Since 1.1.1991, the notifying procedure has also been applied to Eastern Germany. The procedure requires that employers report all information of their employees registered by the social security system to the social security agencies (Statistisches Bundesamt 1993). The informative value of the employment statistics depends essentially on the respective definition of employment covered by social security (s. 2 (1), (2) of the DEVO). It should also be taken into consideration that the person providing the information may change during the time, e.g. because of interfirm mobility. This can also lead to implausible information in the employment history (e.g. change of training or nationality).

*** Figure 2: Notification procedure

The employment statistics include workers, salaried employees and all trainees, as long as they are not exempt from the obligation to pay social insurance contributions. The employment statistics do not include, among others, civil servants, those in marginal employment, students enrolled in higher education and family workers (Cramer 1985). For 1995, the employment statistics cover nearly $79.4 \%$ of all employed persons in Western Germany, and $86.2 \%$ of all employed persons in Eastern Germany, ${ }^{8}$ but the coverage varies over individual occupations and industries (Herberger / Becker 1983). Furthermore, in empirical analyses, it has to be noted that the definition of variables (e.g. wage) may have changed during the past years.

Notifications are prescribed for the beginning and ending of employment. In addition, an annual report must be made for each employee covered by social insurance who is employed on the 31 December of the year (cf. Hoffmann / Wermter 1976). These yearly notifications have the function of stocktaking, because the notifying procedure is

6 A detailed representation of the IAB employment subsample can be found in Bender / Hilzendegen (1995) and in Bender et al. (1996).

7 DEVO (German abbreviation for "Data Acquisition Regulations"; these govern data acquisition by social insurance agencies and were published on 24.11.1972 (BGBl. I:2195 ff.).

DÜVO (German abbreviation for "Data Transmission Regulations""; these govern data transmission on mechanically utilisable data media in the social insurance system and the Federal Employment Service (Bundesanstalt für Arbeit); dated 18.12.1972 (BGBl. I:2482 ff.). Since 1.1.1999 the regulations of a newly introduced procedure for social insurance (DEÜV; BGBl. I, pp. $343 \mathrm{ff}$. Article 1) apply.

8 Calculated on the basis of employed persons (domestic concept) from the Statistisches Bundesamt, Wirtschaft und Statistik 12/1997. 
conceived in such a way that employment must be confirmed in the course of time without any gaps, or concluded by means of a cancellation (Wermter / Cramer 1988). This means that for each employment there is a notification, an annual report in case the employment continues over the end of the year, and a cancellation or termination of the employment, all within statutorily prescribed periods.

The characteristics sex, year of birth, nationality, marital status, number of children and qualifications, are collected for each employee recorded by social insurance. Exact daily data on employment contains information on the occupational code, the occupational status, the gross earnings to the contribution assessment ceiling, an establishment number issued by the Employment Service, the industry and the size of the establishment. ${ }^{9}$ The available characteristics can be divided into two categories. On the one hand, some characteristics (insurance numbers, employment duration and earnings covered by social insurance contributions) mainly serve insurance law purposes. These must be notified with each interfirm change, and are, therefore, very accurate. On the other hand, the IAB employment subsample contains characteristics with purely statistical information. Changes to these characteristics are notified at the end of the year with the annual report (Cramer 1985).

A change of occupation ${ }^{10}$, e.g. is a purely statistical date, but regarding internal mobility the occupational changes are registered late, usually with the next annual report at the end of the year. For this reason, duration of specific employment may be over- or underestimated up to one year, in case the end of the year is used as the change date of occupation. In contrast, changes of occupation with interfirm mobility are recorded exactly, because interfirm mobility must be notified. Fig. 3 shows two hypothetical employment histories. For person A, exact information is available for an employment period covered by social insurance. This information is shown by three notifications of starts, two terminations and four annual reports. For person B there is exactly one employment with three annual reports for the period under consideration. The occupational mobility of person A in 1989 is shown in the data with the exact date, because this is directly linked with interfirm mobility which is subject to notification. In contrast, the occupational mobility of person B in his employment in 1987 is not shown exactly. The change of occupation is not reported to the exact date, but only in the following annual report. This means that there is an underestimation of the duration of the former occupation, and an overestimation of the new occupation, if the actual occupation mobility is set at the end of 1987.

*** Figure 3: (title: Hypothetical employment history and their representation by the notifying procedure)

The problems with earnings are synonymous. It should be noted that earnings represent

9 Regional characteristics are also collected, but these cannot be passed on to users for reasons of data confidentiality.

10 A change of occupation is measured by a change in the occupation code. This means that there is not necessarily a complete reorientation of the activity with a change to the occupation code, e.g Velling / Bender (1994), and the bibliography indicated there. 
information related to duration, so that, for example, increases in earnings during a year in an establishment are averaged for the year. If a person changes the firm within a year it must be taken into account that any special payments, such as Christmas bonuses, are paid by the subsequent employer. These special payments are also averaged over the remaining period, so that any increase in earnings cannot be explained only by the interfirm mobility.

A systematic $1 \%$ sample was taken from the total population of all notifications collected in a file (historic file ${ }^{11}$ ) by the Federal Employment Service since the introduction of the notifying procedure. This sample covers a period of 21 years for Western Germany (1.1.1975 to 31.12.1995) and 4 years for eastern Germany (1.1.1992 to 31.12.1995). The sample's total population consists of all employment cases in occupations covered by social insurance at least once between 1975 and 1995. In the annual averages, the IAB employment subsample includes about 200,000 persons in Western Germany, 52,000 persons in Eastern Germany, and over 559,540 persons in the whole period; this corresponds to about 7.8 million data records. The IAB employment subsample is a longitudinal data set in process ("process-produced"), because the available characteristics are required by the public service to carry out its tasks (Schmähl 1985).

This database is supplemented by data on benefits recipients and by establishment information:

(1) The benefits recipients file contains person-related information on periods in which the Federal Employment Service paid benefits. These periods are periods in which persons draw substitute wage payments from the Federal Employment Service, such as unemployment benefit, unemployment assistance or maintenance payments for advanced vocational training or retraining. This does not cover all possible periods of unemployment. Unless specific preconditions are fulfilled a claimant may draw unemployment benefit (so-called "primary" unemployment assistance ["originäre" Arbeitslosenhilfe). Unemployment assistance is only paid in the case of personal need. In addition, the file does not record all benefits paid by the Federal Employment Service to persons (cf. Bender et al. 1996: 26).

(2) The establishment file contains information on establishments which are notifying, or have notified, employment covered by social insurance. The Federal Employment Service keeps a file containing all establishment numbers which the Employment Offices have ever issued to establishments providing employment. When an establishment number is issued, an attempt is made to keep to the concept of the workplace, but this is not carried out on a uniform basis. The establishment characteristic is supplemented by information on the notifying establishments which, like the historic file, is ascertained from the employment statistics collected by the Federal Employment Office. In contrast to the historic file, existing notifications are not simply filed. Additional information on the establishments is generated from the employment notifications submitted by establishments, because the establishment number provides an unambiguous key characteristic for identifying establishments.

11 The historic file contains information on employment covered by social insurance which has been passed from social insurance agencies to the Federal Employment Service since the notifying procedure was introduced in 1973. The history file is generated from the BA's employment statistics by storing the notifications submitted in previous years through the notifying procedure in archive storage media at the end of a year in accordance with a defined algorithm. 
Using the employment statistics ${ }^{12}$ as a basis, aggregations of the person-related attributes on school and vocational training are carried out in accordance with the establishment characteristic; particularly establishment-related employment figures have been determined on 30 June each year since 1977. However, the proportion of employees covered by social insurance among all employees depends on the industry. For example, a very high degree of coverage can be assumed for manufacturing industry, and a low degree of coverage (up to 50\%) in the services industry (cf. Bender et al. 1996).

As can be seen in Fig. 3, biographical employment history can be reproduced with the IAB employment subsample, in so far as there is any employment covered by social insurance and/or benefits are received (cf. Alba et al. 1994, Bender et al. 1996). Interruptions to employment covered by social insurance may occur which are to the greatest degree nondefined as to their contents (e.g. self-employment, appointment as civil servant, out of labour force, return to home country, social assistance). ${ }^{13}$ These gaps may also be caused by e.g. weekends, so that it is practical to set a defined length for the gaps regarding a contextual interpretation.

Because of the large number of observations (e.g. persons/records), the IAB employment subsample permits differentiated analyses of the above characteristics. In addition, in comparison to social research surveys over time as panels or surveys based on retrospective information there are no problems concerning panel mortality, and there are no error possibilities which have to be taken into account in a retrospective survey of employment history (Bender et al. 1995: 123 f.). These statements will be made clear using an example.

*** Figure 4: Employment and income flow of the system-free personal number 14

Fig. 4 shows the (anonymised) employment and income history of the system-free personal number $14 .{ }^{14}$ Three aspects of the employment and income history (employment status, interfirm or occupational mobility, and flow of income) are shown on two time axes. The corresponding person's age is plotted to the respective year on the lower axis. The person observed (female, German) is 48 years old in 1975 (born 1927). Above this, the calendar time axis is plotted which contains the complete observation period for the IAB employment subsample. In the period of 21 years there are exactly 33 notifications. However, there are no notifications for the start of the period under observation, so that the first notification occurred on 1.2.1977. The end of the observation window was not reached either, because the person observed left the labour force in 1986 at the age of 59 . The employment history is characterised by very brief periods of employment with many periods of drawing benefits.

To enable a more exact observation of the person concerned, information on the

12 The notification procedure can be regarded as a continuous complete population survey of employees covered by social insurance.

13 For example, in Fig. 2, Person A has three gaps (in 1986, 1988 and in 1989/1990).

14 This example is based on an idea by Götz Rohwer (1995) which was extended by the representation of firm and occupation mobility. 
employment status is provided in the bottom part of the figure. The following statuses can be assumed here: "apprentice, trainee, student trainee" (6), "regular gainful employment" (5), "continuing employment without payment" (4), "maintenance allowance from unemployment insurance" (3), "unemployment benefit" (2), "unemployment assistance" (1), and "no information available in the IAB employment subsample" (0). ${ }^{15}$ The income flow $^{16}$ (daily earnings in DM in the period of employment) is shown above this on the basis of the nominal value (broken line) ${ }^{17}$ and the real value (continuous line). The occupational and interfirm mobility can be read off using three statuses - occupational mobility (1), interfirm mobility (2) or simultaneous occupational and interfirm mobility (3).

The person observed starts her employment history in the observation window on 31.5.1977 as a salaried employee. She is employed as an office worker (occupation code 781) in an establishment in the "print" industry (system-free establishment number 223870) until 2.10.1977. Then she starts the first of seven phases drawing benefit (first of all unemployment benefit, and then unemployment assistance) from 2.10.1977 to 6.2.1978. The unemployment phase ends when she starts working for a political party (establishment number 326704). She carries out practically the same work here (stenographer, stenotypist, typist). This period of employment starts on 7.2.1978 and ends on 19.3.1978. Daily earnings with the first and second employers amounts to DM 60 and DM 61. Following a brief break, she starts work again for one week at a much lower rate of pay (DM 34). After another brief break she starts working part-time for a brief period (from 18.6.78 to 19.8.78) at a payment rate of DM 25/day. All these interfirm mobility are linked to (marginal) occupational mobility. After another employment period for about one year, the second period of unemployment starts on 5.6.79, which is also subdivided into a period of drawing unemployment benefit and one in which she received unemployment assistance. (...)

A total of seven unemployment periods are found in just 10 years of employment history. This history also concludes with the longest phase, from 28.4 .82 to 22.5.86. It can be assumed that a pension at the age of 60 after long-term unemployment was applied here. Until then, the person worked in ten different establishments and eight different occupations, whereby the occupation as an office worker was frequently found. Occupations related to the occupations stenographer, stenotypist, typist (782), data typist (783), and office assistant (784) can also be found. A certain degree of occupational mobility can also be seen, with cook (411) from 19.7.80 to 19.12.80, and sales assistant (682) as the final occupation in the employment history. There was an occupational mobility connected with practically every interfirm mobility (seven simultaneous changes).

15 This status can only be shown in a figure by TDA at the start or the end of employment. Gaps in the employment history are, therefore, not displayed in the figure.

16 Information on income is based exclusively on earnings subject to social insurance. In case of unemployment periods contributions from the last months of the employment period are taken over. The sample does not give any information on the level of benefits payments.

17 The cost-of-living index for all private households was used to calculate real earnings (Jahresgutachten des Sachverständigenrates). The cost-of-living index for 1975 (base year) was used as 1. 


\section{The anonymisation of the IAB employment subsample}

The data contained in the employment statistics is social data, and is, therefore, subject to confidentiality according to $\S 35$ of the Social Code, Book I. Under $\S 75$ of the Social Code, Book X, disclosure for research and planning purposes is permitted under certain conditions, but only with clearance from the highest federal or state authorities. This is not an ideal way for a broad use of the database by external researchers. However, anonymised data, in contrast to the data governed by the Federal Statistics Act, is not subject to any further confidentiality. For this reason, the IAB decided on anonymisation; it has kept to factual anonymisation under $\$ 16(6)$ of the Federal Statistics Act, and has also used to a great extent the methods applied during the anonymisation of the German microcensus.

Factual anonymisation means that the amount of time, money and effort subsequently required setting up a link to a person or a establishment (re-identification) from the individual information is out of all proportion. Although subsequent re-identification cannot be ruled out completely, this concept still guarantees sufficient protection for those persons surveyed without restricting the analysis potential of the data by rigid anonymisation procedures (Bender et al. 1995: $122 \mathrm{f}$.). The anonymisation of the IAB employment subsample was an attempt to make the data usable for research as unchanged and complete as possible.

\subsection{Cross-section anonymisation of personal data}

The anonymisation procedures for person-related cross-section information were conducted closely to the results of the project on factual anonymity of the German Microcensus and the Sample Survey of Income and Expenditure (Einkommens- und Verbrauchsstichprobe), which was carried out jointly by the Statistisches Bundesamt (Federal Office of Statistics), the University of Mannheim and ZUMA (Müller et al. 1991). ${ }^{18}$ In accordance to the rules of this project, group characteristics were combined unless their univariate marginal distribution of a cross-section count (30.6) in each year had at least 5,000 employees covered by social insurance in the population (employment statistics). ${ }^{19}$

Starting 1992, the IAB employment subsample 1975-1995 contains data for Eastern Germany. For content-wise reasons, the differentiation between Eastern and Western Germany is of great importance, and the transmission of a characteristic for marking notifications from Eastern Germany has the highest priority above other characteristics (e.g. industry and establishment size). Accordingly, Eastern and Western Germany are regarded as two separate units for anonymisation, i.e. the rules for anonymisation are applied separately to notifications from both parts of the country. In the case of the characteristics "age" and "nationality", migrants between Eastern and Western Germany are treated separately; the rules for Eastern Germany apply to them independently of where they are working at present. The number of regional migrations in the period between 1992

18 The concepts of this project were also taken over, such as, e.g. definitions or the determination of the reidentification risk (cf. Müller et al. 1991; Wirth 1992; Müller et al. 1995, following March et al. 1991, and Pass / Wauschkuhn 1985). An overview of the multilayered aspects of this subject is provided in the special edition of the Journal of official statistics (1993), in particular Keller-McNulty / Unger (1993).

19 An exception is nationality: in this case there have to be 30,000 employees covered by social insurance for each characteristic category. 
and 1995 are found for 13,241 persons (cf. Table 1).

In spite of these rules for anonymisation, a large part of the person-related cross-section information can be passed in the original state, or with only slight modifications. In the following, the central, person-related characteristics and their modifications resulting from the rules for anonymisation will be shown briefly:

In the IAB employment subsample 1975-1995 it is possible for the first time to differentiate between employment in Eastern and Western Germany. The characteristic was generated from the establishment number. ${ }^{20}$

A system-free personal number replaced the insurance number.

A person's sex is a component of the insurance number. This characteristic was not anonymised.

The year of birth is also a component of the insurance number. Anonymisation was carried out at each end of the age distribution only. Because this characteristic is timeconstant, the first, and the last, notification for a person was included to assess an anonymisation. Persons under 16 (on the first notification), or over 66 (on the last notification) in Western Germany, or 63 in Eastern Germany, were each included in one category.

Marital status differentiates between "married" and "single", and is also found in the original status in the anonymised sample.

Number of children: the input of the number of children is based on the information on the tax cards and is available as a continuous characteristic. The characteristic is shown in the original up to seven children; from eight children, the category is "eight and more children".

With regard to nationality it must be stated that the definition of who is a German is found in Art. 116 (1) of the Basic Law. Coding is carried out in accordance with the personal systematics - nationality and area code of the Federal Office of Statistics. 188 nationalities are altogether found in the IAB employment subsample, nine nationalities and seven nationality groups are shown for Western Germany. Because of the extremely low numbers of non-Germans in Eastern Germany, the only differentiation possible here is between Germans and other nationalities.

Education represents the achieved schooling and concluded vocational training in eight categories. The schooling categories "lower and middle secondary school" and "upper secondary school leaving certificate (university entrance level) are subdivided into the education categories "no vocational training" and "completed vocational training". In addition, there are categories for "completed non-university higher education", "university degree", "education not known" and "missing". Anonymisation procedures were not carried out.

The occupational code refers directly to the job contents. Allocation in this category is

20 The difference is seen in the first digit of the eight-digit establishment number: establishments in eastern Germany have 0 here. 
carried out in accordance with the code list from the Federal Employment Service (1975) with a three-digit code. Of the 334 occupations, 234 are retained in their original classification for Western Germany; the remaining 100 were reclassified to form 41 occupational groups. In the case of Eastern Germany, 111 occupations can still be passed on in their original classification; the remaining 224 were aggregated to form 81 occupational groups.

The employment status differentiates for those in full-time employment between " apprentice, trainee, student trainee", "unskilled worker", "skilled worker", "master craftsman, foreman", "salaried employee" and "outworker". In addition, a differentiation is made between two groups of part-time employees in accordance with the ratio between contractually agreed and the usual working hours in a establishment; there is no information for these groups regarding their employment status. It was possible to adopt this characteristic without any anonymisation measures.

The gross pay subject to social insurance contributions is given for each notification at the end of an employment period and in each annual report. The upper limit is the contribution assessment ceiling for pensions insurance, which is adapted annually to the developments in wages and salaries, and the lower limit is the pay limit for those in marginal employment. A daily income was calculated from the wages sum for a notification period and this is found in an exact sum in DM between the contribution assessment ceilings. In contrast to the older version of the IAB employment subsample, the pay is no longer rounded, but is shown truncated to the respective daily income. There was a change in the definition of income in 1984, so the researcher has to keep this in mind for longitudinal analysis (Steiner / Wagner 1997).

The benefits recipients file is used to form the three statements 1. unemployment benefit and comparable benefits (e.g. unemployment allowances, settling-in allowances for the unemployed, severance payments), 2. unemployment assistance and comparable benefits (e.g. unemployment assistance for members of the armed forces on short-term contracts), and 3. maintenance allowances and comparable benefits (e.g. settling-in allowances on further training / retraining, or for German language courses) from over 60 different types of benefit. This large number of benefit types arises from a series of procedural changes which have their basis in amendments to the Employment Promotion Act ("Arbeitsförderungsgesetz").

\subsection{Cross-section anonymisation of establishment information}

There is still a lack of usable, practical systematic knowledge regarding the anonymisation of establishments (cf. Brand et al. 1999). However, it is still assumed that the risk of reidentification, and the benefit of de-anonymisation, increases with the size of an establishment. To allow the subdivision into Eastern and Western Germany, with a detailed list of industries and establishment sizes, no other regional characteristics have been taken into consideration. Approximations of characteristics were carried out using a three-dimensional table (establishment size * industry * east/west). Taking the whole population (establishment file in the employment statistics) as a basis, each occupied cell of this cross table had to contain no less than three establishments, at least after an 
aggregation of the characteristics. In the case of the few clearly identifiable establishments additional anonymisations were carried out (e.g. grouping establishments into a single establishment) (Bender / Hilzendegen 1995, Bender et al. 1996).

Establishment characteristics and changes to them arising from the anonymisation rules are briefly shown below:

The establishment number is issued to employers by the Employment Offices. A systemfree establishment number replaces it.

The industry is assigned to a three-digit code of the establishment number and is in accordance with the list of industries used for the statistics of the Federal Employment Service (1973 edition). To protect anonymity, this code is usually shown as two digits; however, the specific nature of the information depends on the size of the establishment and on the differentiation Eastern/Western Germany.

The establishment size is calculated on the basis of the establishment number from the quarterly file of the employment statistics (30.6) as a continuous variable, only refering to the employees covered by the social insurance system under an establishment number. In the anonymised file there are eight (Western Germany) and seven (Eastern Germany) establishment size classes and a missing category. Special rules apply to establishments which change their size over time, and to clearly identifiable establishments.

The establishment's first and last notification year is supplied from the IAB's establishment file. This file is available for the years 1977 to 1995 . This means that a difference can be made between voluntary and involuntary firm mobility. However, deletion of an establishment number does not necessarily accompany the bankruptcy of an establishment. An establishment's first and last notification year may in fact be shifted by one year (in both directions) through the longitudinal anonymisation. A certain degree of inaccuracy at the current boundary is possible as a result of delayed notifications.

Three proportion values are formed from the aggregation of establishment numbers in the establishment file. These are: the proportion of employees covered by social insurance with university-equivalent qualifications or university degrees, the proportion of employees covered by social insurance who have completed vocational training, and the proportion of employees covered by social insurance who have not completed vocational training. This information is given in integer percentage values.

\subsection{The anonymisation of the longitudinal information on the personal level}

The aim of anonymisation of the longitudinal information is to make it at least more difficult to date notifiable events exactly. The daily accuracy results directly from the tasks of the notification procedure (e.g. calculating pension rights). The characteristic features of the notification procedure in fact make re-identification attempts more difficult, because notified and actually perceived events in the employment history may diverge (e.g. mistaken memory during retrospective surveys). This means that the indicated duration does not usually coincide with the actual number of days worked, but refers to employment covered by social insurance, which contains among other things work-free days (e.g. 
Sundays), holidays and/or sick days (Bender et al. 1995).

In order to prevent changes to the arrangement of events with one another with regard to time and to the duration of episodes, the complete employment history for each employee (all periods of employment and of drawing benefits) was shifted along the time axis by a constant amount to anonymise the longitudinal information. The individual shift constant for the complete employment biography of an individual was stipulated by drawing an independent identical normal distributed random variable with the expectation value zero.

To retain the structure of the data record annual reports had to be artificially generated, under specific conditions. These additional notifications do not affect analyses regarding content (BENDER et al. 1996). Mobility (mostly internal) that did not have to be notified (e.g. change of occupation) remains as annual reports, in accordance with the logic of the notification procedure. If it is assumed that this mobility takes place exactly at the end of the year, and not during the year, the first or the last episode of a status that does not have to be notified can be reduced or lengthened by the amount of the shift constant.

Anonymisation of the longitudinal information causes problems for cross-section analyses which are linked to defined historical periods. However, if massive effects are linked to the key date, for example seasonal effects on unemployment in certain industries, this effect will be smudged with time through the anonymisation and will appear less concise the greater the variance of the random shift is (Wiedenbeck / Schimpl-Neimanns 1994: $1 \mathrm{f}$.).

\section{Cross-section comparison of the anonymised and the original IAB employment subsample 1975-1995}

Although one aim of the factual anonymisation was to make the data utilisable for researchers as unchanged as possible, the above-named data modifications had to be carried out. The question is now how far the anonymisation procedures have affected the data quality, and therefore the analysis potential. The results of a comparison of the anonymised and the original IAB employment subsample 1975-1995 will be presented for this purpose.

In a first step, simple frequencies on a defined key date (30.2.1989) will be calculated for both samples (i.e. the anonymised and the original IAB employment subsample 19751990) and compared. The comparison of the two samples will include only those persons who did not have a single multiple employment relationship in the observation window. Because the observation window for some persons in the original sample is up to 3 years longer (1973, 1974 and 1991), persons who had a multiple employment relationship in these three years were excluded from the analysis. This can result in deviations in the numbers of persons between the two samples. The characteristics "employment status" (cf. Table 2) and "occupation code" (cf. Table 3) will be presented. In the anonymised sample, the occupation code covers 234 of the 334 occupation codes, so that the eight occupations with the highest frequencies are shown below.

There are no large deviations between the anonymised and the original IAB employment subsample. The 30th June each year is, after the end of the year, the date with the greatest mobility in the file, so that frequencies of the stock with the anonymised sample at defined historical points present no problems. 
To enable statements to be made on mobility at defined historical points, interfirm mobility between 30.6.92 and 4.8.93 was observed (entry date). There was an interfirm mobility of 49,319 persons for the anonymised sample, and 49,525 changes for the original sample. If the interfirm mobility in the original IAB employment subsample (cf. Fig. 5) is observed, a very high mobility rate can be seen at the end of the year (9,771 changes of establishment). In addition, a specific pattern can be recognized at the end of the month or at weekends. The distribution in the anonymised IAB employment subsample is dominated by the shift in interfirm mobility to the end of the year (cf. Fig. 6). The frequent interfirm mobility to the end of a month or a week has completely vanished. This means that the aim of the anonymisation (making it more difficult to date notifiable events exactly to the day) has been reached. Movements which are not exact to the day and which are linked to specific historical points can be traced back with the anonymised IAB employment subsample.

*** Figure 5: Interfirm mobility between 30.6 .92 and 4.8 .93 in the original IAB employment subsample

*** Figure 6: Interfirm mobility between 30.6 .92 and 4.8 .93 in the anonymised IAB employment subsample

5. Comparison of a multivariate analysis of the anonymised and the original IAB employment subsample 1975-1990 - the mobility of persons who have completed the German apprenticeship system

A multivariate model will be used below to clarify whether the differences ascertained above in the time location of events have an effect on the results of multivariate models. The model in Bender / Seifert (1996) was used; the authors examined whether migrants who run through the German apprenticeship system ("dual system") have similar labour market chances as natives. ${ }^{21}$ Because the terms of reference (sampling, anonymisation rules) have not changed at all, the results can be transferred directly to the IAB employment subsample 1975-1995.

There are three problems, which will be briefly sketched here, with tracing males who have successfully completed the dual system. It has to be ensured that those who have successfully completed the dual system are at the beginning of their working careers. For this reason, only those persons were included who were not older than 15 years in 1975 (year of birth: 1960). ${ }^{22}$ The IAB employment subsample stores trainees and student trainees under a joint code number together with those who are actually in the German apprenticeship system. Notification of the end of training is not a notifiable event for the

21 In the following, the main interest is the comparison of the results of the anonymised and the original IAB employment subsample, so that an interpretation of the results are largely done without. Readers are referred to Bender / Seifert (1996).

22 This means that the examined population is filled up year for year, and grows from 1,064 (end of 1976) to 73,101 (1990). Different durations for the individual entry cohorts result in the observation window, so that earlier entry cohorts have a greater probability of implementing their first status change. This circumstance is taken into account by forming dummy variables for the entry cohorts. 
period under observation (1975-1990). Getting for certain only the people who end the German apprenticeship system, in the following analysis only training contracts are observed which last longer than 450 days. The duration of training in the case of those who have successfully completed training and have been taken on by their training establishment can be underestimated up to one year. ${ }^{23}$ In the case of this group there may be different training duration between the anonymised and the original IAB employment subsample. Among other things, the anonymisation of the longitudinal information can shorten the training duration of those who continue working at their training establishments and this can explain the differences between the extent of mobility in the two samples. ${ }^{24}$

An immediate (direct) change of occupation is measured as the first form of mobility. The notification of the previous occupation and of the subsequent occupation must not be interrupted by a period of drawing benefits, or may not be longer than 30 days apart (break in employment covered by social insurance). The two other forms of transition (from employment to drawing benefits, or to a break in employment covered by social insurance) are viewed separately. Accordingly, each person can change his recognised training occupation directly, or can become unemployed, or interrupt employment covered by social insurance. These three possible transitions are assessed in a model with competing risks. $^{25}$

The process time for the following event-oriented modelling is counted from the last training notification, because this is the only way in which off-the-job and internal mobility can be treated equally. The model is calculated with episode splitting, because each notifiable change (e.g. interfirm mobility) is displayed immediately and nonnotifiable changes only with the annual report.

For the analysis, a generalisation of the exponential model is selected, the piecewise constant exponential model. The basic idea is to divide the time axis into single time intervals and to assume that the transition rate within a period is constant, but varies between time intervals. This procedure has some advantages: "It is particularly helpful when researchers are not in a position to measure and include important time-dependent covariates explicitly or when they do not have a clear idea about the form of the timedependence of the process." (Blossfeld / Rohwer 1995: 100).

The general concept of event data analyses is the time-dependent risk function. ${ }^{26}$ The duration in employment covered by social insurance is shown as $t$ and the risk of leaving this is designated $r(t)$ (transition rate). $r(t)$ is dependent on the duration of employment, then:

$$
\mathrm{r}(\mathrm{t})=\lim _{\mathrm{t}^{\prime} \rightarrow \mathrm{t}} \frac{\operatorname{Pr}\left(\mathrm{t} \leq \mathrm{T}<\mathrm{t}^{\prime} \mid \mathrm{T} \geq \mathrm{t}\right)}{\mathrm{t}^{\prime}-\mathrm{t}} \quad \text { for } t<t^{\prime}
$$

23 This means that the above setting does not correspond to a statutory regulation of the dual system, but results directly from the notification procedure.

24 This analysis does not take into account any multiple employment either, so that the above arguments for the cross-section comparison apply as well.

25 Bender / Seifert (1996) observe the first three transitions for men and women. For reasons of clarity, only the first transition from the training occupation is shown here.

26 The following representation is closely based on Blossfeld / Rohwer (1995). 
$\operatorname{Pr}\left(t \leq T<t^{\prime} \mid T \geq t\right)$ is the conditional probability of a transition after $t$ days of employment covered by social insurance in the following time interval $t^{\prime}$. The basic model can be formulated as follows:

$r(t)=g(t, x)$

According to this, the transition rate is dependent on the time and the covariates $(x)$.

If $f(t)$ is defined as the density function of the duration of employment covered by social insurance, and $G(t)$ as the survival function which gives the proportion of persons still in the same employment, then:

$\mathrm{r}(\mathrm{t})=\frac{f(t)}{G(t)}$

In the piecewise constant exponential model, the time axis has to be divided into intervals:

$0=\tau_{1}<\tau_{2}<\tau_{3}<\ldots<\tau_{L}$

With $\tau_{L+1}=\infty$ there are $L$ time intervals

$$
I_{l}=\left\{t \mid \tau_{l} \leq t<\tau_{l+1}\right\} \quad l=1, \ldots, L .
$$

If these time intervals are given, the transition rate from original state $j$ to target state $k$ is defined as follows:

$$
r_{j k}(t)=\exp \left\{\bar{\alpha}_{l}^{(j k)}+A^{(j k)} \alpha^{(j k)}\right\} \text { if } t \in I_{l} .
$$

For each transition $(j, k)$ a constant coefficient $\bar{\alpha}_{l}^{(j k)}$ is linked with the $l$-th time interval. $A^{(j k)}$ is a (line) vector of the covariates, and $\alpha^{(j k)}$ is the appropriate vector of the coefficients which remains constant over the time interval (BLOSSFELD/ROHWER 1995).

The variables for the event analysis were operationalised as follows:

- The duration of employment is recorded in days.

- The nationality (dummy) assumes the value 1 for non-Germans.

- Education is recorded in 3 dummies: (1) without university entrance qualifications, (2) with university entrance qualifications, (3) education unknown.

- Six dummies are formed for the industry: (1) industry unknown, (2) agriculture, (3) manufacturing industry, (4) construction, (5) distribution, and (6) other services.

- Five dummies are shown for the establishment size: (1) establishment size not known, (2) $1-9$, , (3) $10-49$, (4) 50-499, and (5) over 500 employees covered by social insurance.

- The cost-of-living index for all private households is used as the base for the real earning (log.) in the establishment of origin (Sachverständigenrat zur Begutachtung der gesamtwirtschaftlichen Entwicklung 1991). ${ }^{27}$

27 Because it is difficult to calculate wages for multiple employment, only employees covered by social insurance without multiple employment are observed in the analyses. 
- A dummy, which controls the period of less than 900 days since the first notification in the file.

- Ten dummies which control the entry cohorts in the file (before 1979, 1980, 1981, .. 1987, after 1988) because there are different censoring probabilities for these cohorts.

If we examine the results of the piecewise constant exponential model (cf. Table 4), no differences can be ascertained between the anonymised and the original sample. All three baselines run the same course, none of the coefficients of the covariates displays any differences. Observed changes are in the significance levels of agriculture and the distribution sector on transition to drawing benefits, and of the establishment size of 50499 employees covered by social insurance on transition to breaks and to a second occupation. This means that it is irrelevant for this analysis whether it is carried out with the anonymised or with the original IAB employment subsample.

Non-German employees do not change their occupations significantly after completing the German apprenticeship system, and no difference between Germans and non-Germans on transition to drawing benefits can be ascertained. However, there is a significant effect of non-Germans on transition to a break in employment covered by social insurance. Because these breaks are to the greatest extent undefined as to their contents, it cannot be ascertained whether non-Germans differ from Germans with regard to not drawing benefits, changing to self-employment or a general withdrawal from the German employment market. In spite of this, the analysis provides some indications that the occupational success of migrants depends on their level of education (in this case, taking part in the dual system of vocational training) (cf. Bender / Seifert 1996).

\section{Conclusion}

With the different versions of the IAB employment subsample researchers have a rich source of data available to them. The anonymisation rules appear to be generally accepted. This can be seen not only in the relatively high number of users but also in the various publications media.

Users of the anonymised IAB employment subsample are, however, unable to estimate the "damage" anonymisation causes for scientific analyses. This was attempted in the present paper, together with a detailed presentation of the data. As a result it may be stated that only the distribution of interfirm mobility over the time axis cannot be traced with the anonymised IAB employment subsample. In contrast, with cross-section comparisons at an historic point in time (30.6.89), only small deviations were ascertainable between the anonymised and the original IAB employment subsample. The results of a multivariate model (piecewise constant exponential model), which aims at daily precision, also do not show any significant deviations in the results between the two datasets. This means that the comparisons of the anonymised and the original IAB employment subsample have shown that the anonymisation measures do not essentially restrict the analysis potential of the anonymised data. ${ }^{28}$

In spite of now having the second version of the anonymised IAB employment subsample available, it still cannot be said that there is systematic access to this data source for researchers. The financing of an anonymisation is too cumbersome, the time intervals for

28 However, further comparisons will have to be made to create a broader base for this statement. 
updates are too arbitrary, and the results depend very much on the respective source of financing. Although a lot has already been done in this area, it is essential to search for more suitable paths for anonymisation projects.

This path is already worthwhile for the currently available data material. However, the complete analysis of this data source has still not been utilised with the present anonymised IAB employment subsample. Additional establishment information could be generated from the present material which could then be used for analyses (cf. Bender et al. 1999a). A merge with social surveys is also possible. For example, the establishment number can be used to build up a so-called employer-employee data set with the IAB establishment panel (c.f. Bellmann et al. 1999; Bender et al. 1999a,b as a first example). However, in Germany the anonymisation of establishment information is still not fully clarified, although initial considerations on this subject can be found (Brand et al. 1999 a,b). It is also conceivable that surveys on the level of persons are merged with the process-produced data found here. The IAB is carrying out a pilot project on this in conjunction with the Max Planck Institute for Educational Research in Berlin, in which the retrospective information from cohorts 1964 and 1971 is linked to data from the employment statistics via the insurance number.

Hopefully, a uniform European Data Protection Act will allow this data to be passed on outside Germany. The anonymised IAB employment subsample, which is available to researchers through the Central Archive for Empirical Social Research at the University of Cologne (ZA), is one of the most important sources of data for labour market research. 


\section{Literature}

Alba, R.D. / Müller, W. / Schimpl-Neimanns, B. (1994): Secondary Analysis of Official Statistics. In: Borg, I. / Mohler, P. PH. (eds.): Trends and Perspectives in Empirical Social Research. Berlin, New York, de Gryter, p. 57-78.

Bellmann, L. / Bender, S. / Schank, T. (1999): Flexibilität der Qualifikationsstruktur aus betrieblicher Sicht: Substitutionalität oder Komplementarität, Jahrbücher für Nationalökonomie und Statistik, Bd. (Vol.) 219/1+2, p. 109-126.

Bender, S. / Haas, A. / Klose, C. (1999): Mobilität allein kann Arbeitsmarktprobleme nicht lösen. Die Entwicklung der beruflichen und betrieblichen Mobilität von 1985 bis 1995, IABkurzbericht, Nr.2, IAB, Nürnberg.

Bender, S. / Hilzendegen, J. (1995): Die IAB-Beschäftigtenstichprobe als scientific use file, Mitteilungen aus der Arbeitsmarkt- und Berufsforschung 1, p. 76-95.

Bender, S. / Hilzendegen, J. / Schimpl-Neimanns, B. (1995): Die IABBeschäftigtenstichprobe: eine neue Datei für die Arbeitsmarktforschung, ZUMA-Nachrichten 36, p. 122-129.

Bender, S. / Hilzendegen, J. / Rohwer, G. / Rudolph, H. (1996): Die IABBeschäftigtenstichprobe 1975-1990, Beiträge zur Arbeitsmarkt- und Berufsforschung 197, Nürnberg, IAB.

Bender, S. / Konietzka, D. / Sopp, P. (1999): Flexibilisierung oder Marginalisierung? Erwerbsverläufe ,Jenseits des Normalarbeitsverhältnisses“ im Arbeitsmarkt der 1990er Jahre, paper, (Nürnberg, Rostock).

Bender, S. / Preißler, J. / Wübbeke, C. (1999): Die Dynamik der betrieblichen Altersstruktur vor dem Hintergrund betrieblicher Entscheidungen, paper, Nürnberg.

Bender, S. / Seifert, W. (1996): Zuwanderer auf dem Arbeitsmarkt: Nationalitäten- und geschlechtsspezifische Unterschiede, Zeitschrift für Soziologie 6, p. 473-495.

Blossfeld, H.P./ Rohwer, G. (1995): Techniques of Event History Modeling - New Approaches to Causal Analysis. Hillsdale.

Brand, R. / Bender, S. / Kohaut, S. (1999): Possibilities for the Creation of a Scientific-Use File for the IAB-Establishment-Panel erscheint in: Proceedings of the Joint Eurostat/UNECE Work Session on Statistical Data Protection 1999.

Cramer, U. (1985): Probleme der Genauigkeit der Beschäftigtenstatistik, Allgemeines Statistisches Archiv 69, p. 56-68.

Haas, A. / Hilzendegen, J. (1997b): Ein neuer Datensatz der IAB-Beschäftigtenstichprobe jetzt im Zentralarchiv verfügbar: der Regionaldatenfile, ZA-Information 40, p.10-14.

Herberger, L. / Becker, H. (1983): Sozialversicherungspflichtig Beschäftigte in der Beschäftigtenstatistik und im Mikrozensus, Wirtschaft und Statistik, p. 290 - 304.

Hoffmann, H.P. / Wermter, W. (1976): Die Beschäftigtenstatistik der Bundesanstalt für Arbeit - ihr Informationsgehalt, das Auswertungsprogramm und seine Realisierung, Arbeit und Beruf 27, p. 33 - 36.

Keller-McNulty, S. / Unger, E. (1993): Database Systems: Inferential Security; In: Journal of Official Statistics 2, p. 475-517.

Lancaster, T. (1990): The Econometric Analysis of Transition Data; Cambridge: University Press. 
Marsh, C. / Skinner, C. / Arber, S. / Penhale, B. / Openshaw, S. / Hobercroft, J. / Lievesley, D. / Walford, N. (1991): The Case for Samples of Anonymized Records from the 1991 Census; In: Journal of the Royal Statistical Society, 154, p. 305-340.

Müller, W./Blien, U./Knoche, P./Wirth, H. unter der Mitarbeit von Beckmann, P./ Bender, S./Helmcke, T./Müller, M. (1991): Die faktische Anonymität von Mikrodaten; Stuttgart, Metzler-Poeschel.

Müller, W. / Blien, U. / Wirth, H. (1995): Identification Risks of Microdata - Evidence from Experimental Studies; In: Sociological Methods \& Research 24, p. 131-157.

Pass, G. / Wauschkuhn, U. (1985): Datenzugang, Datenschutz und Anonymisierung. Analysepotential und Identifizierbarkeit von anonymisierten Individualdaten; München, Wien, R. Oldenbourg.

Rohwer, G. (1994): TDA Working Papers; Bremen.

Rohwer, G. (1996): TDA User's Manual - Version 6.0; Berlin.

Rohwer, G. / Pötter, U. (1999): TDA User’s Manual - Version 6.2; Bochum,

Sachverständigenrat zur Begutachtung der gesamtwirtschaftlichen Entwicklung (1991); Jahresgutachten 1991/1992, Stuttgart und Mainz.

Schmähl, W. (1985): Prozeßproduzierte Längsschnittinformationen zur Einkommensanalyse - Anmerkungen zu den Datenquellen; Allgemeines Statistisches Archiv 69, p. 275 - 285.

Steiner, V./Wagner, K. (1997): Entwicklung der Ungleichheit der Erwerbseinkommen in Westdeutschland, Mitteilungen aus der Arbeitsmarkt- und Berufsforschung 30, p. 638-651.

Velling, J. / Bender, S. (1994): Berufliche Mobilität zur Anpassung struktureller Diskrepanzen im Arbeitsmarkt, Mitteilungen aus der Arbeitsmarkt- und Berufsforschung 3, p. 212-231.

Wermter, W./Cramer, U. (1988): Wie hoch war der Beschäftigtenanstieg seit 1983 - Ein Diskussionsbeitrag aus der Sicht der Beschäftigtenstatistik der Bundesanstalt für Arbeit, Mitteilungen aus der Arbeitsmarkt- und Berufsforschung 21, p. 408 - 482.

Wiedenbeck, M. / Schimpl-Neimanns, B. (1994): Robustheit von Ereignisanalysen bei längsschnittanonymisierten Daten der Beschäftigtenstatistik des IAB. Mannheim.

ZA-Information (1996): Zentralarchiv für empirische Sozialforschung an der Unversität zu Köln, IAB-Beschäftigtenstichprobe, Nr.38, p. 15-19.

Wirth, H. (1992): Die faktische Anonymität von Mikrodaten: Ergebnisse und Konsequenzen eines Forschungsprojektes. In: ZUMA-Nachrichten 30, p. 7-65.

\section{Appendix}

Baltagi, B.H. / Blien, U. (1998): The German Wage Curve: Evidence from the IAB Employment Sample, Economics Letters 61, p. 135-142.

Bauer, T. (1998): Arbeitsmarkteffekte der Migration und Einwanderungspolitik: Eine Analyse für die Bundesrepublik Deutschland, Heidelberg. Physika-Verlag.

Bauer, T. / Pereira, P./ Vogler, M. / Zimmermann, K.F. (1998): Portuguese Migrants in the German Labor Market: Performance and Self-Selection, IZA Discussion Paper No. 20, Bonn, 1998.

Bellmann, L. / Bender, S. / Hornsteiner, U. (1997): Interfirm Job Mobility of Two Cohorts 
of Young German Men 1979-1990, Discussion Paper des Sonderforschungsbereich 386.

Bellmann, L. / Möller, J. (1995): Institutional Influences on Interindustry Wage Differentials, in: Buttler, F. / Franz, W. / Schettkat, R. / Soskice, D.(Hrsg.), Institutional Frameworks and Labor Market Performance - Comparative Views on the U.S. and German Economies, London, New York: Routledge, p. 132-167.

Bender, S. / Fahrmeir, L. / Lang, S. (1999): Determinanten der Arbeitslosigkeit in Westdeutschland, in: Felix Buechel, Martin Diewald, Peter Krause, Antje Mertens und Heike Solga (Hrsg.): Soziale Ausgrenzung am deutschen Arbeitsmarkt, Leske + Budrich, Leverkusen.

Blien, U. (1995): The Impact of Unemployment on Wage Formation. Estimating Wage Curves for Western Germany with Multilevel Linear Models, in: Gerlach, K. / Schettkat, R. (1995) (Hrsg.): Determinanten der Lohnbildung. Theoretische und empirische Untersuchungen. Berlin: Edition Sigma.

Blien, U. / Mederer, A. (1998): Regional Determinants of Gender Specific Wages, in: Haslinger, F. / Stönner-Venkatarama, O. (Hrsg.): Aspects of the Distribution of Income, Marburg: Metropolis.

Burda, M. / Mertens, A., (1998): Wages and Worker Displacement in Germany, CEPR Discussion Paper 1869.

Fitzenberger, B. / Franz, W. (1999): Flexibilität der qualifikatorischen Lohnstruktur und Lastverteilung der Arbeitslosigkeit: Eine ökonometrische Analyse für Westdeutschland, in: Gahlen, B. / Hesse, H. and Ramser, H.J. (Ed.): Verteilungsprobleme der Gegenwart Diagnose und Therapie, Wirtschaftswissenschaftliches Seminar Ottobeuren, Band 27, Mohr Siebeck, p.47-85.

Fitzenberger, B. (1999): Wages and Employment across Skill Groups - An Analysis for West Germany, Physica Verlag: Berlin.

Fitzenberger, B. (1999): International Trade and the Skill Structure of Wages and Employment in West Germany, Jahrbücher für Nationalökonomie und Statistik, 219/1+2, p. 67-89.

Mavromaras, K. G./ Rudolph, H. (1997): Wage Discrimination in the Re-Employment Process, Journal of Human Resources Vol.32, No.4, Fall 1997, p. 812-860.

Mavromaras, Kostas G. / Rudolph, Helmut (1998a): Temporary Separations and Firm Size in the German Labour Market, Oxford Bulletin of Economics and Statistics, Vol.60, No.2, May 1998, p.215-226.

Mavromaras, Kostas G. / Rudolph, Helmut (1998b): Verteilungseffekte der Arbeitslosenversicherung in Deutschland in den 80er Jahren, Mitteilungen aus der Arbeitsmarkt- und Berufsforschung, 31. Jg., Heft 1, p. 93-107.

Mertens, A. (1998): Labor Mobility and Wage Dynamics - An Empirical Study for Germany in Comparison with the United States, Ph.D. thesis Humboldt University Berlin and Aachen: Shaker Verlag. 
Möller, J. (1999): Die Entwicklung der qualifikatorischen Lohn- und Beschäftigungsstruktur in Deutschland - Eine empirische Bestandsaufnahme (Changes of the Structure of Wages and Employment with Respect to Qualifications in Germany - An Empirical Analysis), in: Jahrbücher für Nationalökonomie und Statistik, 219 (1-2), p. 8-31. 
Table 1: Numbers of east/west or west/east migrations separately for Germans and other nationalities

$N=534,839$

\section{Migration, or no migration}

East/west migration, or west/east

\section{No. of persons affected}

$351 \quad(0.5 \%) \quad$ Other nationalities

$12,890(2.5 \%)$ Germans

69,711 (99.5\%) Other nationalities

$501,887(97.5 \%)$ Germans

Table 2: Frequencies of the employment status for 30.6 .1992 (West Germany), anonymised and original IAB employment subsample

\begin{tabular}{|l|l|l|l|l|}
\hline & \multicolumn{3}{|l|}{ Anonymous } & \multicolumn{2}{l|}{ Original } \\
& $\mathrm{N}$ & $\%$ & $\mathrm{~N}$ & $\%$ \\
\hline Apprentices, trainees, student trainees & 13,194 & 5.65 & 13,469 & 5.76 \\
Unskilled workers & 48,841 & 20.92 & 48,965 & 20.93 \\
Skilled workers & 48,844 & 20.92 & 48,804 & 20.86 \\
Master craftsman, foreman & 3,918 & 1.68 & 3,922 & 1.68 \\
Salaried employees & 91,203 & 39.06 & 91,241 & 38.99 \\
Homeworkers & 311 & 0.13 & 312 & 0.13 \\
Part-time, less than half of full-time & 4,752 & 2.04 & 4,762 & 2.04 \\
working hours & & & & \\
Part-time, more than half of full-time & 22,440 & 9.61 & 22,497 & 9.61 \\
working hours & 10 & 0.00 & 10 & 0.00 \\
Missing & 233,513 & 100.00 & 233,982 & 100.00 \\
\hline Total & & & & \\
\hline
\end{tabular}

Table 3: Frequencies of occupations (occupation code) for 30.6 .1992 (West Germany), anonymised and original IAB employment subsample (extract)

\begin{tabular}{|l|l|l|l|l|}
\hline & \multicolumn{3}{l|}{ Anonymous } & \multicolumn{2}{l|}{ Original } \\
& $\mathrm{N}$ & $\%$ & $\mathrm{~N}$ & $\%$ \\
\hline Sales staff (682) & 11,760 & 17.12 & 11,840 & 17.19 \\
Banking staff (691) & 5,320 & 7.74 & 5,311 & 7.71 \\
Drivers (714) & 6,602 & 9.61 & 6,599 & 9.58 \\
Business owners, chief executives (751) & 3,512 & 5.11 & 3,520 & 5.11 \\
Office workers (781) & 28,013 & 40.78 & 28,050 & 40.72 \\
Nurses (male and female) (853) & 4,469 & 6.51 & 4,485 & 6.51 \\
Receptionists (856) & 3,766 & 5.48 & 3,801 & 5.52 \\
Cleaners (933) & 5,255 & 7.65 & 5,285 & 7.67 \\
\hline Total & 68,697 & 100.00 & 68,891 & 100.00 \\
\hline
\end{tabular}


Table 4: Mobility of males who have completed the dual system of vocational training; piecewise constant exponential model

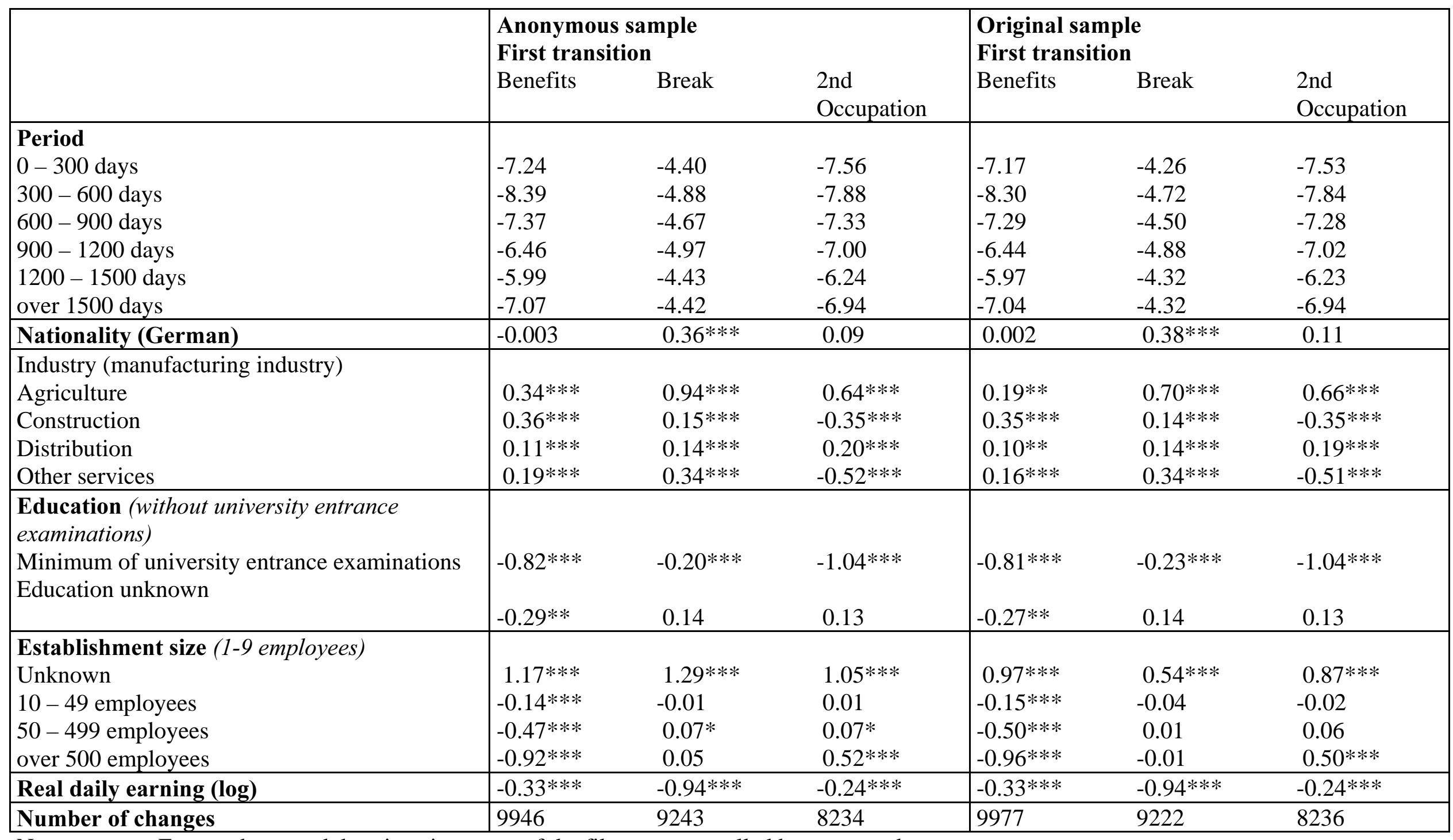

Notes: $\quad$ Entry cohorts and duration since start of the file were controlled but are not shown.

$* * *$ Significant at $\mathrm{p}<=.001 ; * *$ significant at $\mathrm{p}<=.01$; significant at $\mathrm{p}<=.05$. Reference categories shown in brackets. 
Anonymous

sample

Original

sample

Log likelihood (zero $\quad-467812.40$ model):

Log likelihood (estimated $\quad-440434.02$ model):
$-469004.40$

$-442268.59$ 
Figure 1: Data access

\section{USER}

Project application with title, duration, project staff and project description

Signature

Pays ZA fees
ZA

Formal test

User contract drawn up

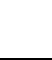

Anonymised IAB

employment subsample /

TDA 6.2
IAB

Formal test

Approved 
Figure 2: $\quad$ Notification procedure

$\begin{array}{lll}\begin{array}{l}\text { Pension insurance } \\ \text { agency }\end{array} & \text { Employee } & \text { Employer } \\ & & \text { Establishment } \\ & \text { number office } \\ & \text { Establishment no. }\end{array}$

Employment

Notification situations

Notifications to

Member stock
Collection offices for sickness
insurance
Check of completeness, plausibility, notification sequence

Insurance contributions

Pensions account

Pension insurance agency data office, Federal Employment Service

Federal Employment Service Employment statistics

Archive file

Current file

Establishment file Regional code WZW code

Annual period material

(2 years)

Quarterly file Stocks

Started and ended employment (6 months)

History file

IAB sample

(total material) (account adjusted)

Benefits recipients file (ALG/ALH/UHG)

ALG = Unemployment benefit

ALHI $=$ Unemployment assistance

$\mathrm{UHG}=$ Maintenance allowance 
Figure 3

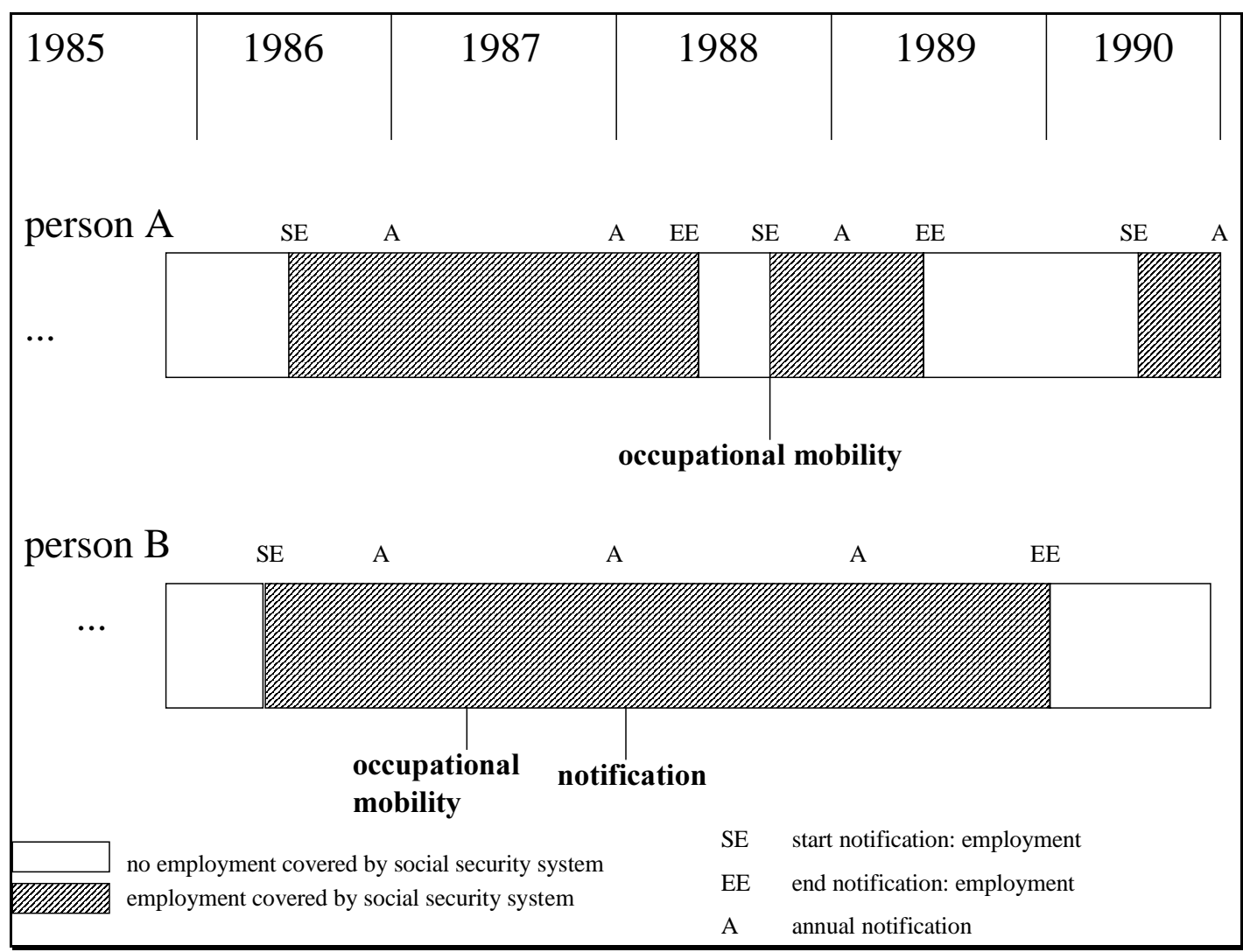



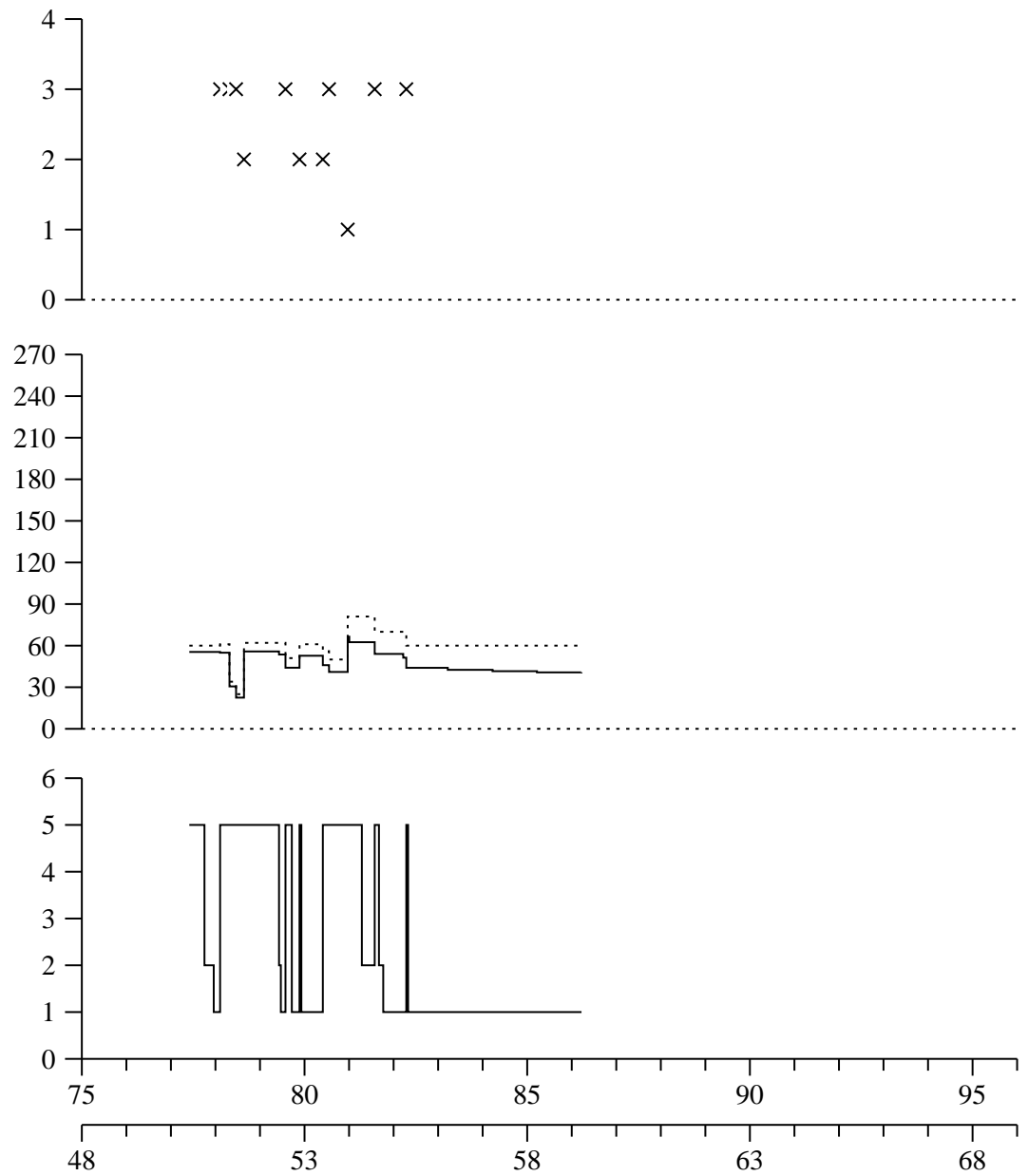


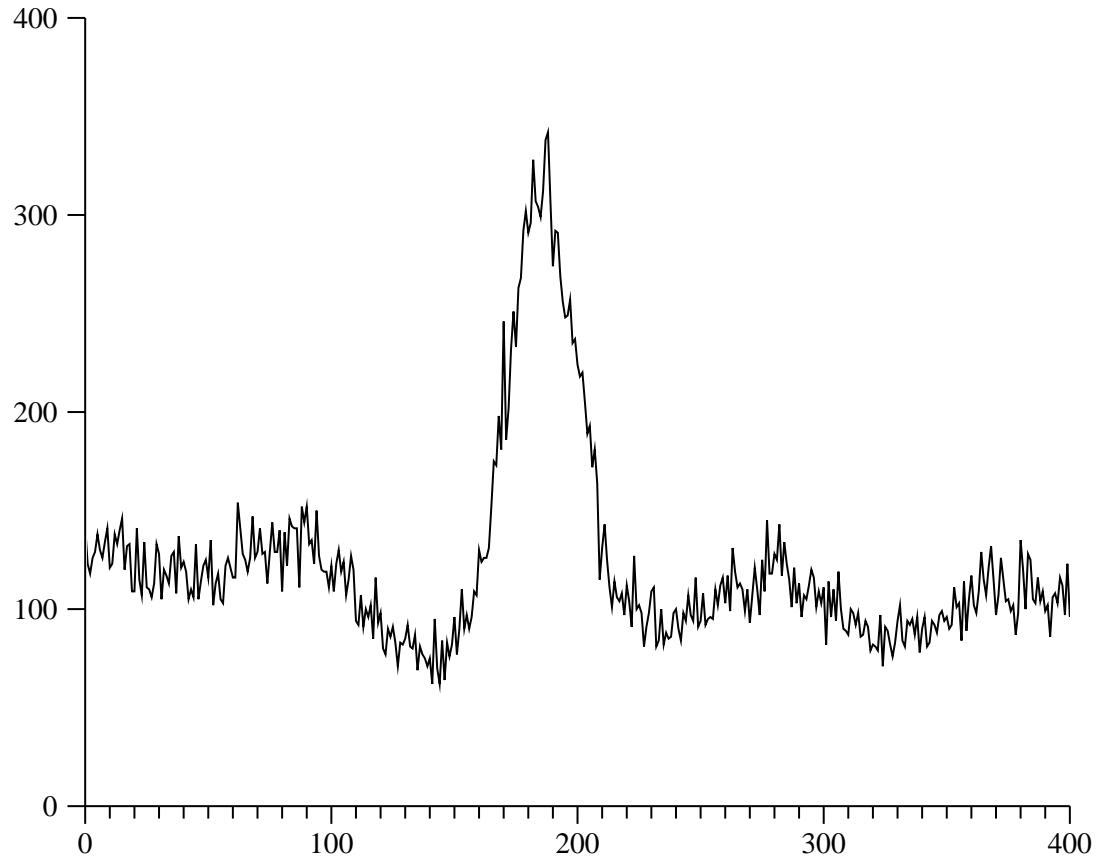




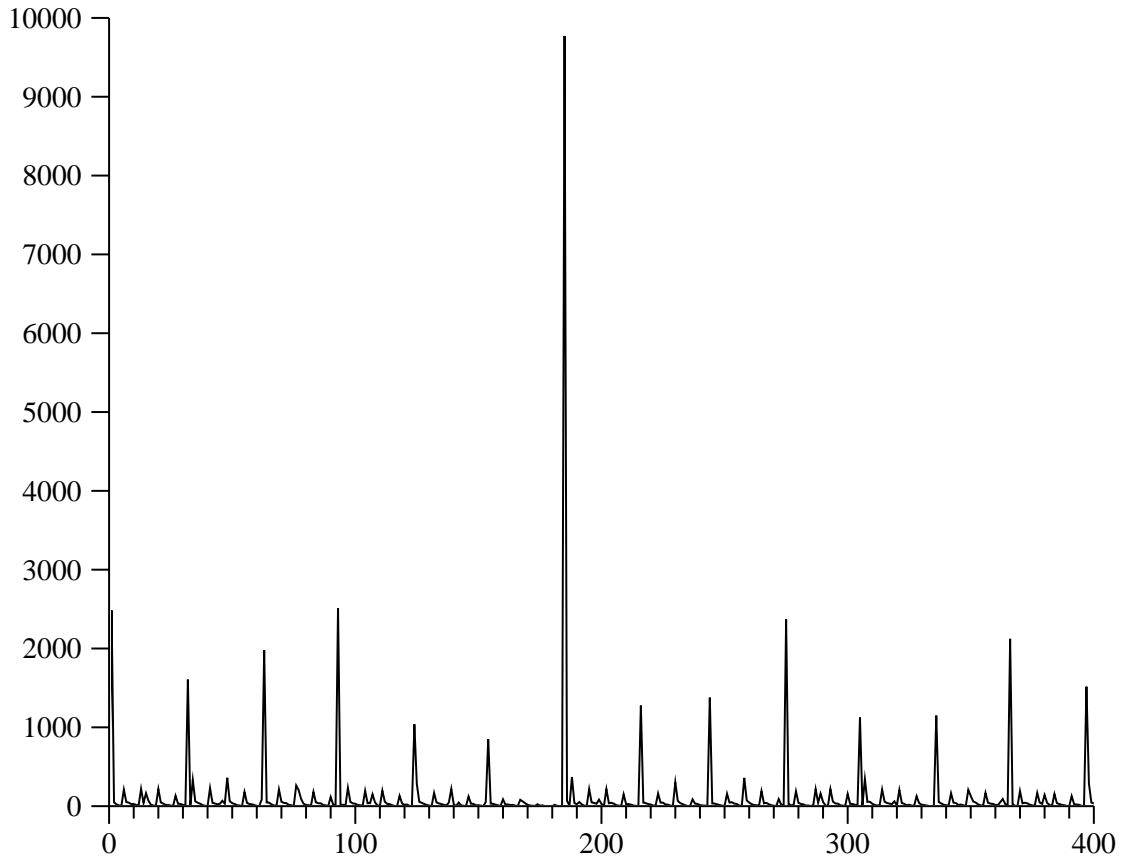




\section{IZA Discussion Papers}

No. Author(s)

21
J. Ondrich
C. K. Spiess
Q. Yang
G. G. Wagner

22
A. Million
R. Rotte
K. F. Zimmermann

23

T. Bauer

K. F. Zimmermann

24 K. F. Zimmermann

M. C. Burda

J. von Hagen

K. Konrad

F. Schneider

G. G. Wagner

K. Papps

R. Winkelmann

26

D. Enste

F. Schneider

27

E. Bratberg

$\varnothing$. A. Nilsen

28

U. Broll

K. P. Wong

D. J. Snower

30

J. Kluve

H. Lehmann

C. M. Schmidt

31

C. M. Schmidt

32

S.- A. Dahl

$\varnothing$. A. Nilsen

K. Vaage

A. Lindbeck

D. J. Snower

34
Title

Area

Date

The Liberalization of Maternity Leave Policy and

$1 / 3$

9/98

the Return to Work after Childbirth in Germany

The Economics of Hospital Trips and Health Care 3

$9 / 98$

Reform

Learning Efficiency of Economics Students

7

$9 / 98$

Petersberger Erklärung: Anstöße für eine

$1 / 3$

$10 / 98$

zukunftsgerichtete Arbeitsmarktpolitik

Unemployment and Crime: New Answers to an

Old Question

Increasing Shadow Economies All Over the

World - Fiction or Reality?

Transitions from School to Work: Search Time and Job Duration

Efficiency Wages and Futures Markets

$1 / 7$

$1 / 99$

Causes of Changing Earnings Inequality

Active Labor Market Policies in Poland:

$1 / 99$

Human Capital Enhancement, Stigmatization or Benefit Churning?

Persistence and the German Unemployment

Problem: Empirical Evidence on German Labor Market Flows

Work or Retirement? Exit Routes for Norwegian Elderly

Price Dynamics and Production Lags 
Is Job Stability in the United States Falling?

Reconciling Trends in the Current Population

1

Survey and Panel Study of Income Dynamics

The Effects of European Economic and Monetary

Union on Wage Behaviour

37 H. S. Buscher

Exchange Rate Volatility Effects on the German

Job Satisfaction within the Scottish Academic

Multi-Task Learning and the Reorganization of

Work

Empirical Findings on the Swiss Migration

Anatomy of Policy Complementarities

Household Characteristics, Ability and Education: Evidence from a Dynamic Expected Utility Model

The Effects of Development on Migration:

Theoretical Issues and New Empirical Evidence

Tenure-based Wage Setting

Overtime Work and Overtime Compensation in Germany

51 A. Barrett

P. J. O'Connell
J. Mayer
R. T. Riphahn

Ethnic German Migration After 1989 - Balance and Perspectives

Does Training Generally Work?

The Returns to In-Company Training

Fertility Assimilation of Immigrants: Evidence from Count Data Models

Inter-industry Wage Dispersion in Portugal: high 7 but falling 


\begin{tabular}{|c|c|c|c|c|}
\hline 55 & L. Goerke & $\begin{array}{l}\text { Value-added Tax versus Social Security } \\
\text { Contributions }\end{array}$ & 3 & $8 / 99$ \\
\hline 56 & $\begin{array}{l}\text { A. Lindbeck } \\
\text { D. J. Snower }\end{array}$ & $\begin{array}{l}\text { Centralized Bargaining and Reorganized Work: } \\
\text { Are they compatible? }\end{array}$ & $1 / 5$ & 9/99 \\
\hline 57 & $\begin{array}{l}\text { I. N. Gang } \\
\text { K. F. Zimmermann }\end{array}$ & $\begin{array}{l}\text { Is Child like Parent? } \\
\text { Educational Attainment and Ethnic Origin }\end{array}$ & 1 & $9 / 99$ \\
\hline 58 & $\begin{array}{l}\text { T. Bauer } \\
\text { K. F. Zimmermann }\end{array}$ & Occupational Mobility of Ethnic Migrants & 1 & 9/99 \\
\hline 59 & $\begin{array}{l}\text { D. J. DeVoretz } \\
\text { S. A. Laryea }\end{array}$ & $\begin{array}{l}\text { Canadian Immigration Experience: } \\
\text { Any Lessons for Europe? }\end{array}$ & $1 / 2 / 3$ & 9/99 \\
\hline 60 & $\begin{array}{l}\text { C. Belzil } \\
\text { J. Hansen }\end{array}$ & $\begin{array}{l}\text { Subjective Discount Rates, Intergenerational } \\
\text { Transfers and the Return to Schooling }\end{array}$ & 7 & $10 / 99$ \\
\hline 61 & R. Winkelmann & Immigration: The New Zealand Experience & 7 & $10 / 99$ \\
\hline 62 & A. Thalmaier & $\begin{array}{l}\text { Bestimmungsgründe von Fehlzeiten: Welche } \\
\text { Rolle spielt die Arbeitslosigkeit? }\end{array}$ & 3 & $10 / 99$ \\
\hline 63 & M. Ward & Your Everyday, Average Academic & 5 & $10 / 99$ \\
\hline 64 & M. Ward & $\begin{array}{l}\text { Salary and the Gender Salary Gap in the } \\
\text { Academic Profession }\end{array}$ & 5 & $10 / 99$ \\
\hline 65 & $\begin{array}{l}\text { H. Lehmann } \\
\text { J. Wadsworth } \\
\text { A. Acquisti }\end{array}$ & $\begin{array}{l}\text { Grime and Punishment: Job Insecurity and Wage } \\
\text { Arrears in the Russian Federation }\end{array}$ & 4 & $10 / 99$ \\
\hline 66 & $\begin{array}{l}\text { E. J. Bird } \\
\text { H. Kayser } \\
\text { J. R. Frick } \\
\text { G. G. Wagner }\end{array}$ & $\begin{array}{l}\text { The Immigrant Welfare Effect: Take-Up or } \\
\text { Eligibility? }\end{array}$ & 3 & $10 / 99$ \\
\hline 67 & $\begin{array}{l}\text { R. T. Riphahn } \\
\text { A. Thalmaier }\end{array}$ & $\begin{array}{l}\text { Behavioral Effects of Probation Periods: } \\
\text { An Analysis of Worker Absenteeism }\end{array}$ & $1 / 3$ & $10 / 99$ \\
\hline 68 & B. Dietz & $\begin{array}{l}\text { Ethnic German Immigration from Eastern Europe } \\
\text { and the former Soviet Union to Germany: the } \\
\text { Effects of Migrant Networks }\end{array}$ & 1 & $11 / 99$ \\
\hline 69 & M.-S. Yun & $\begin{array}{l}\text { Generalized Selection Bias and the Decomposition } \\
\text { of Wage Differentials }\end{array}$ & 7 & $11 / 99$ \\
\hline 70 & $\begin{array}{l}\text { I. N. Gang } \\
\text { F.L. Rivera-Batiz }\end{array}$ & $\begin{array}{l}\text { Immigrants and Unemployment in the European } \\
\text { Community }\end{array}$ & 1 & $11 / 99$ \\
\hline 71 & L. Goerke & The Wedge & 3 & $11 / 99$ \\
\hline 72 & $\begin{array}{l}\text { J. Fersterer } \\
\text { R. Winter-Ebmer }\end{array}$ & $\begin{array}{l}\text { Are Austrian Returns to Education Falling Over } \\
\text { Time? }\end{array}$ & 7 & $11 / 99$ \\
\hline 73 & $\begin{array}{l}\text { G. S. Epstein } \\
\text { S. Nitzan }\end{array}$ & The Endogenous Determination of Minimum Wage & 3 & $11 / 99$ \\
\hline
\end{tabular}


Knowing What Works: The Case for Rigorous

Entry Decision into Self-Employment from Transition Economies

80 J. C. van Ours

The Netherlands: Old Emigrants - Young 
An Evaluation of Public Employment Programmes in the East German State of Sachsen-Anhalt

97 A. Barrett

L. Husted

H. S. Nielsen

M. Rosholm

N. Smith

102 B. van der Klaauw

J. C. van Ours

K. Brännäs

104

S. Kohns

105
G. Brunello
C. Graziano
B. Parigi

106
L. Bellmann
S. Bender
U. Hornsteiner

107 J. C. van Ours

G. Ridder

108 J. Boone

J. C. van Ours

109 G. J. van den Berg

B. van der Klaauw

D. DeVoretz

C. Werner
Irish Migration: Characteristics, Causes and 1 Consequences

Industry Wage Differentials Revisited: A

Longitudinal Comparison of Germany and USA

Residential Location and Youth Unemployment:

\section{Transitions}

Immigrant Assimilation and Welfare Participation: 1/3/7

Do Immigrants Assimilate Into or Out-of Welfare?

Employment and Wage Assimilation of Male First 3 Generation Immigrants in Denmark

Estimation in a Duration Model for Evaluating

Different Skill Levels and Firing Costs in a

Matching Model with Uncertainty -

An Extension of Mortensen and Pissarides (1994)

Ownership or Performance: What Determines

Board of Directors' Turnover in Italy?

Job Tenure of Two Cohorts of Young German Men
1979 - 1990: An analysis of the (West-)German Employment Statistic Register Sample concerning multivariate failure times and unobserved heterogeneity

Fast Track or Failure: A Study of the Completion Rates of Graduate Students in Economics

Modeling Financial Incentives to Get Unemployed

Back to Work

Combining Micro and Macro Unemployment 
112 L. Bellmann

A Comparative Look at the Czech Republic

Innovations, Wages and Demand for

113 R. Euwals

Heterogeneous Labour: New Evidence from a

Matched Employer-Employee Data-Set

Do Mandatory Pensions Decrease Household Savings? Evidence for the Netherlands

114 G. Brunello

A. Medio

115 A. Cigno

F. C. Rosati

116 C. Belzil

117 S. Bender
A. Haas
C. Klose

An Explanation of International Differences in Education and Workplace Training

Why do Indian Children Work, and is it Bad for Them?

Unemployment Insurance and Subsequent Job Duration: Job Matching vs. Unobserved Heterogeneity

IAB Employment Subsample 1975-1995. Opportunities for Analysis Provided by the Anonymised Subsample 